\title{
9. ALTERATION OF UPPERMOST LAVAS AND VOLCANICLASTICS RECOVERED DURING LEG 152 TO THE EAST GREENLAND MARGIN ${ }^{1}$
}

\author{
Mary Anne Holmes²
}

\begin{abstract}
During the last stages of the eruption of syn-rift basalts along the East Greenland Margin, debris flows and/or pyroclastic deposits were emplaced at Ocean Drilling Program Sites 915 and 916. The deposits and the tops of the lava flows at Site 918 were altered by subaerial weathering processes as indicated by downhole changes in mineral and chemical composition, and by the mineral paragenesis. Kaolinite and goethite, which form in acidic waters, are abundant at the tops of the weathering profiles and decrease in abundance downward. They are replaced by a smectite-hematite-opal assemblage at the bases of the weathered profiles. Gibbsite is a minor component in the upper parts of the profiles. Good preservation of parent structure and stratification indicate that only the bases of paleosols are preserved at all sites. The upper parts were probably eroded when these sites subsided below sea level.

Abundant gibbsite in marine sediment overlying the paleosols and of middle to late Eocene age is probably derived from the erosion of highly weathered soils formed in a subtropical to tropical climate. A highly weathered basaltic terrane supplied abundant iron oxides in addition to gibbsite, kaolinite, illite/mica, and quartz through fluvially dominated deltaic systems on the shelf through at least the late Eocene. Only small amounts of sediment spilled over into the adjacent Irminger Basin through the Eocene, as indicated by the presence of felsic terrane-derived minerals (quartz, illite, and/or mica). Sedimentation rates were low enough in the Irminger Basin to allow Mn oxide crusts to develop until quartzose turbidites spilled over in the late Oligocene. Gibbsite was not detected in sediment of early Oligocene age and younger, suggesting a regional cooling, increased aridity, and/or leveling of the source area at this time.
\end{abstract}

\section{INTRODUCTION}

Ocean Drilling Program (ODP) Leg 152 sailed to the East Greenland Margin to $63^{\circ} \mathrm{N}$ latitude and recovered sediment from a transect of six drill sites (Fig. 1). The first four, Sites 914-917, were drilled in relatively shallow water depths $(510-530 \mathrm{~m})$ on the southeast Greenland Shelf (Fig. 2; Larsen, Saunders, Clift, et al., 1994). The latter two, Sites 918-919, were drilled in the adjacent Irminger Basin, in water depths of 1850-2100 m. On the shelf in this area, glaciogenic sediment (Quaternary?) unconformably overlies Eocene-Oligocene sediment that, in turn, overlies weathered basalt. The lavas of the basaltic basement were subaerially erupted during the formation of this volcanic, rifted margin (Larsen, Saunders, Clift, et al., 1994). Basalt ages were determined using ${ }^{39} \mathrm{Ar} /{ }^{40} \mathrm{Ar}$ isotopes by Sinton and Duncan (this volume). The ages range from latest Maastrichtian (68.2 \pm 1.6 Ma) to late Paleocene $(60.4 \pm 0.7 \mathrm{Ma})$. Weathering of the youngest lavas presumably dates from this time.

Pre-glacial sediment from the shelf includes paleosols formed from subaerially weathered basalt and "laterite-derivative facies" (sensu Goldbery, 1982), the latter being sediment derived from heavily (i.e., lateritic) weathered material. This study addresses the extent of soil development and preservation on the shelf and at Site 918 in the Irminger Basin, and interprets paleoclimate and landscape development as recorded in the paleosols and their eroded derivatives.

Previously, a paleosol was recovered in the region from Site 336, located atop the Iceland-Faeroe Ridge (Fig. 1). A 30-m-thick subaerially weathered interval was identified above basalt and beneath 400

${ }^{1}$ Saunders, A.D., Larsen, H.C., and Wise, S.W., Jr. (Eds.), 1998. Proc. ODP, Sci. Results, 152: College Station, TX (Ocean Drilling Program).

${ }^{2}$ University of Nebraska-Lincoln, Department of Geology, 214 Bessey Hall, Lincoln, NE 68588, U.S.A. mholmes@unlinfo.unl.edu m of marine sediment by Nilsen and Kerr (1978) in core material recovered during Deep Sea Drilling Project (DSDP) Leg 38 in the North Atlantic. The interpretation that the red clay is a paleosol was largely based on downhole variations in the chemical and mineral composition. The types of variations demonstrated for the red clay at Site 336 are typical of a subaerial weathering environment (Birke-

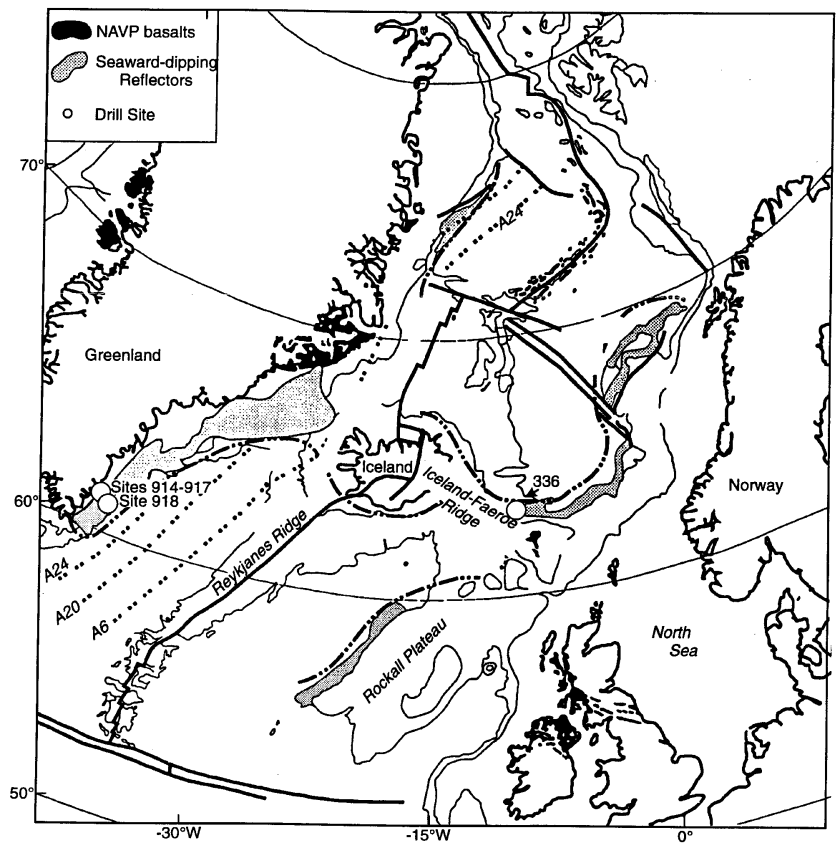

Figure 1. Location of drill sites with paleosols and laterite-derivative facies from ODP and DSDP cores in the North Atlantic. 


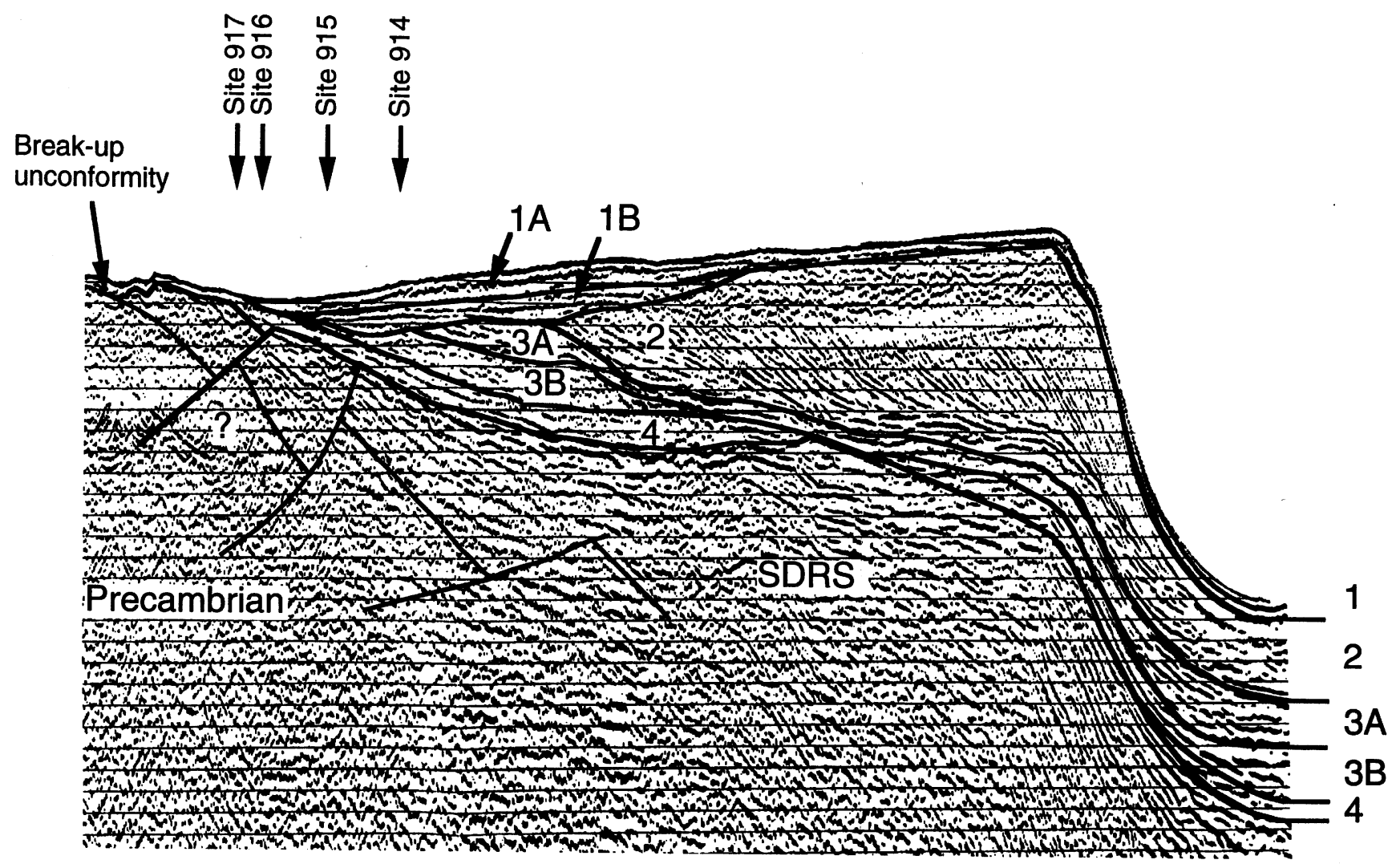

Figure 2 Seismic reflection survey of East Greenland Shelf, showing drill sites for Leg 152.

land, 1984). The paleosol is thought to be a component of the Thulean land bridge, which allowed the free exchange of mammalian fauna between North America and Europe until the late Eocene.

Paleosols can provide a detailed geologic history of a region that no other source can provide, based on morphological characteristics of the weathered zone. Weathered basaltic material, some of it in situ and some of it transported, was recovered from Sites 915, 916, 917, and 918 and is the focus of this study.

\section{METHODS}

Samples were taken from the uppermost lava flows and from volcaniclastic sediment immediately overlying basement from Sites 915, 916, 917, and 918. A few samples from Hole 914A were examined as well. Material highly altered to clay and, in some cases, reddened by oxidation was selected for study. Seven samples were prepared as thin sections using the method for soft samples of replacing moisture with ethanol and acetone prior to resin impregnation (Miller, 1988). The remaining samples were split for various analyses. One split was wet-sieved for grain-size and mineralogic analyses. Another split was used for determination of major, minor, and selected trace elements by energy dispersive X-ray fluorescence analysis (EDXRF) on pressed pellets (Knudsen et al., 1981).

Samples used for grain-size and mineralogic analyses were treated as follows: after a subsplit was taken for moisture determination, the remaining moist sample was weighed and soaked in a $10 \% \mathrm{Cal}-$ gon solution (X-rayed and determined to be various sodium phosphates) overnight. The sample was then placed in an ultrasound bath for up to three 2-min intervals to remove clay from larger size particles. Soaked samples were then wet-sieved using a $64-\mu \mathrm{m}$ screen. Sand-sized particles caught on the screen were dried in an oven at $105^{\circ} \mathrm{C}$ overnight and weighed. Dry sand weight over dry sample weight (i.e., corrected for moisture content) is given as "\% Sand." Silt- and clay-sized particles that passed through the screen were rinsed in alternate solutions of Calgon and distilled water, placed in a centrifuge, and the supernatant decanted up to six times to effect deflocculation.

Deflocculated (washed) fines were then analyzed using a Sedigraph Model 5000ET for grain-size distribution (size range 64-0.25 $\mu \mathrm{m})$. Following grain-size analysis, a $<40-\mu \mathrm{m}$ and a $<2-\mu \mathrm{m}$ size fraction were extracted using the centrifuge to settle larger-size particles following the method of Jackson (1975). These samples were suctioned onto a cellulose nitrate filter membrane using a Milipore filtration apparatus, and the sample was transferred to a glass slide for Xray diffraction (XRD) analysis (Drever, 1973).

Mounted samples were scanned from $2^{\circ}$ to $45^{\circ} 2 \theta$ on a Scintag PAD V X-ray diffractometer that was equipped with a graphite monochromator using $\mathrm{CuK} \alpha$ radiation at $40 \mathrm{kV}$ and $35 \mathrm{~mA}$. Samples with peaks between 11 and $17 \AA$ were treated with ethylene glycol by placing them in a desiccator over ethylene glycol and heating in an oven at $65^{\circ} \mathrm{C}$ overnight. These samples were scanned again from $2^{\circ}$ to $30^{\circ} 2 \theta$ for smectite identification. All samples were heated to $350^{\circ} \mathrm{C}$ for $2 \mathrm{hr}$ to collapse expandable clays and scanned again from $2^{\circ}$ to $15^{\circ} 2 \theta$ for chlorite determination.

Minerals were identified from diffraction data as illustrated in the various figures, following guidelines in standard references (Brown and Brindley, 1980; Brown, 1980; Moore and Reynolds, 1989). Identification of silica phases followed Jones and Segnit (1971). The peak at $10 \AA$ was generally sharp $\left(<0.2^{\circ} 2 \theta\right.$ at half height; Reynolds, 1980$)$, but spread and exhibited asymmetry at the base upon ethylene glycol solvation. This suggests the presence of a well-crystallized illite (W. D. Huff, pers. comm., 1996). Relative abundances of minerals in the $<2 \mu \mathrm{m}$ fraction were determined from diffractograms using peak areas as determined by Scintag's software, DMS v. 2.1. Weighted peak areas (Biscaye, 1965) for the clay minerals were normalized to 100. 
Several samples were also analyzed using NEWMOD and MIXER software (Reynolds, 1980), and good agreement was noted between the two methods for clay mineral abundance. For illustration of general trends, percentage values were assigned an integer value as follows for the accompanying diagrams: $0 \%=0 ; 1 \%-30 \%=1 ; 31 \%-$ $60 \%=2$; and $>61 \%=3$. Relative peak heights within one drillhole are used as a semiquantitative estimate for gibbsite, with integer values assigned as follows: $0=$ absent; 1 = peak height below median value for a given hole; and $2=$ peak height above median value for a given hole.

\section{SEDIMENT DESCRIPTIONS AND ANALYTICAL RESULTS}

\section{Site 915: Basal Weathered Unit}

Lithologic Unit III lies above oxidized, vesicular basalt in Core 152-915A-23R (187.1-189.3 meters below seafloor [mbsf]; Fig. 3), and includes two types of deposits. The upper is a 1.2 -m-thick basalt cobble conglomerate, and the lower is a weathered zone, $105 \mathrm{~cm}$ thick. The weathered zone is composed of yellow to brownish red material with three distinct sediment types. The upper $26 \mathrm{~cm}$ of the weathered zone, volcanic silty clay, is highly altered basalt, with only remnants of parent structure still visible (Pl. 1, Fig. 1). A v-shaped, tapering-downward feature suggests a root trace (Pl. 1, Fig. 1). The interior of the structure is red and hematite-rich, while the exterior is yellow and goethite-rich. Hematite is generally dissolved and removed around decaying root structures (Schwertmann and Taylor, 1989), suggesting that this feature is probably not a root trace but an outline of the edges of two boulders that have been intensely weathered. Beneath the volcanic silty clay, $43 \mathrm{~cm}$ of very poorly sorted sediment has a matrix of volcanic silty clay that hosts clasts up to $6 \mathrm{~cm}$ in diameter (Pl. 1, Figs. 2, 3). It is crudely bedded. Weakly developed normal grading occurs at interval 152-915A-23R-2, 42-70 cm. All of the clasts are volcanic, although they differ in color, composition, and degree of alteration. Some clasts appear as fresher basalt with alteration mineral-filled vesicles, others are composed of a dark green clay, and still others of a bright red clay. The basal $35 \mathrm{~cm}$ of this unit is highly altered, red, vesicular basalt, with vesicles filled in by white and green clay.

The matrix of this weathered unit comprise smectite group minerals, kaolinite, and goethite. Kaolinite dominates the upper $30 \mathrm{~cm}$, through the highly altered zone and into the underlying crudely laminated zone. Within the crudely laminated zone and persisting to the base of the unit, smectite group mineral(s) dominate and goethite levels decline. Aluminum levels decrease over the interval, as do the mobile bases, $\mathrm{Ca}, \mathrm{Mg}$, and $\mathrm{K}$ (relative to $\mathrm{Al}$ content) and the Si content as well (relative to the $\mathrm{Al}$ and/or Fe content). The minerals filling the vesicles are dominantly kaolinite (the white fill), with smaller amounts of smectite (the green outline).

\section{Site 915: Other Laterite-Derivative Facies}

Late middle Eocene to latest Eocene age sediment, lithologic Unit II, overlies the altered basalt and volcaniclastic sediment of lithologic Unit III (Fig. 3). Unit II is $102.3 \mathrm{~m}$ thick and is divided into three subunits. The upper and lower subunits are identical: they are massive, black to dark gray, volcaniclastic sandy silt to silty clay that is rich in glaucony. Several thin, highly bioturbated sand beds occur within the silt or clay, each around $30 \mathrm{~cm}$ thick. The sand beds were interpreted as storm deposits that punctuated deposition in an otherwise quiet outer shelf environment (Larsen, Saunders, Clift, et al., 1994). Between the upper and lower subunits is a 19.2-m-thick dusky red, laminated, volcaniclastic clayey silt with sand (Pl. 1, Fig. 4). Shipboard smear slide examination revealed that the red color arises from abundant ferruginous floccules. Smectite, illite, kaolinite, gibbsite, and goethite comprise the clay fraction throughout this lithologic unit, but their proportions differ among the subunits (Fig. 3). Kaolinite and gibbsite are most abundant in the dusky red clay subunit, while smectite dominates in the lower black silt (Fig. 3). Illite first appears uphole in Sample 152-915A-22R-3, 32-34 cm, dated as middle Eocene age (nannofossil Biozone CP14a; Larsen, Saunders, Clift, et al., 1994). Its abundance is sporadic in younger sediment, but it is generally most abundant in the dusky red silt.

\section{Site 916}

Two lithologic units recovered beneath glaciogenic sediment in Hole 916A bear elements indicative of their derivation from highly weathered basaltic terranes (Fig. 4). The younger lithologic Unit II is an undated, 18.1-m-thick, dark brown to black, volcaniclastic silt to silty sandstone, bearing bright red ferruginous particles, wood fragments, and entire leaf fossils. It lies beneath calcite-cemented, basalt cobble conglomerate similar to that recovered at Sites 917 and 915 and is dated as CP10 or early Eocene age by palynomorphs (Jolley, this volume) (Fig. 4). Light bands showing ripples, convolute laminae, and thin coarsening- and fining-upward beds are composed dominantly of siderite (Pl. 1, Fig. 5). A few escape burrows occur, and these are largely altered to pyrite. Three coarsening-upward sequences, 1-3 m thick, were observed within the unit, which was interpreted as deltaic in origin (Larsen, Saunders, Clift, et al., 1994).

Underlying the deltaic sediment is lithologic Unit III, $5.5 \mathrm{~m}$ of matrix-supported volcaniclastic breccia, recovered in two cores (Fig. 4). The sediment in each core is distinctive. The upper Core 152916A-14R contains $2 \mathrm{~m}$ of massive, poorly sorted, dusky red to bluish gray volcaniclastic conglomerate. Gravel-size rock fragments are all volcanic and vary in color, composition, and degree of alteration. Some clasts have alteration haloes evidently formed prior to deposition, as the degree and nature of alteration varies from one clast to another. While indurated, the sediment is not welded and may have formed as a debris flow or possibly lahar (Larsen, Saunders, Clift, et al., 1994). The lower Core 152-916A-15R contains $3.5 \mathrm{~m}$ of volcaniclastic conglomerate, but this sediment differs from that in the upper core by the absence of hard rock clasts. Beds are weakly developed and are $5-50 \mathrm{~cm}$ thick. In some of the beds, soft clay pebbles of various colors occur. These pebbles were compacted by burial of overlying sediment as indicated by their mutually conforming shapes ( $\mathrm{Pl}$. 1, Fig. 6). A dendritic calcite vein, $25 \mathrm{~cm}$ wide, cuts across interval 152-916A-15R-2, 15-48 cm (Pl. 2, Fig. 1).

The clay fraction of the deltaic sediment, lithologic Unit II, comprises dominant smectite, some kaolinite, and traces of both illite and gibbsite (Fig. 4). The silt fraction includes feldspar, opal-CT, siderite, and quartz. The upper part of lithologic Unit III contains smectite, kaolinite, traces of gibbsite, goethite and clinoptilolite, and has no illite. The lower part of the unit, Core 152-916A-15R, contains a very different assemblage: kaolinite dominates, followed by goethite, and there is only a trace of smectite in one sample within the calcite vein (Fig. 4). Opal-CT (identified by XRD) is common, and a trace of gibbsite occurs in alternate samples. Aluminum is concentrated in the upper parts of both the debris flow from Core 152-916A-14R and the soft-clay pebbles of Core 152-916A-15R, while the bases are depleted relative to $\mathrm{Al}$ over the same intervals (Fig. 5). No $\mathrm{Mg}$, and very low levels of $\mathrm{K}$ and $\mathrm{Ca}$ were detected in this lower interval, but all appear slightly elevated, along with $\mathrm{Si}$ and Fe contents, in the calcitic, hydrothermal vein (Fig. 6). Grain size is much finer in the vein as well. Some clay enrichment occurs in the top of the debris flow unit and this enrichment is accompanied by an increase in gibbsite and goethite levels (Fig. 6).

\section{Site 917}

A 62-cm-thick sedimentary unit is intercalated between lava flows in Core 152-917A-23R (Pl. 2, Figs. 2, 3). The sequence fines upward from crudely cross-bedded gravel, with clasts up to several 


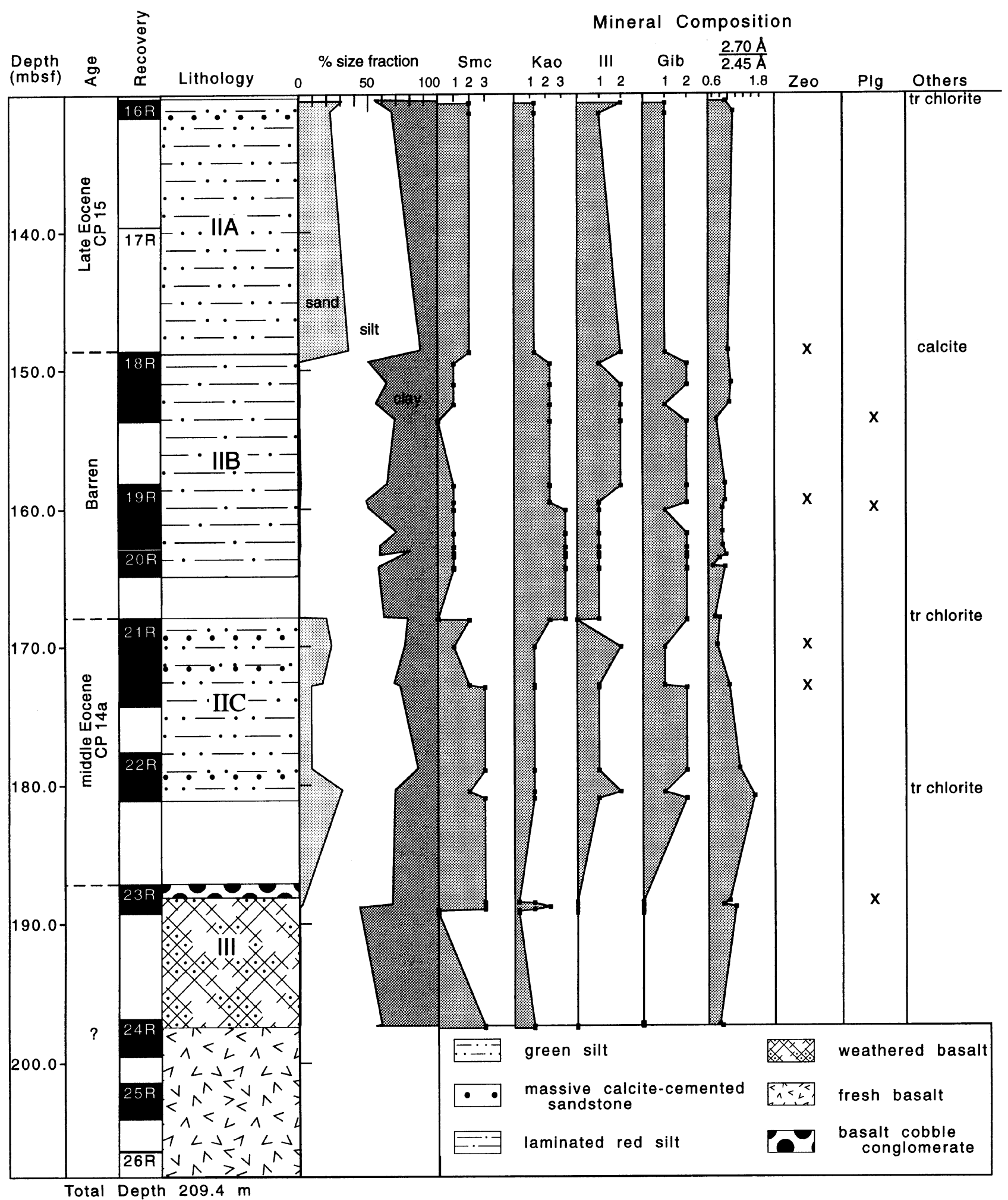

Figure 3. Lithostratigraphy of weathered basement and laterite-derivative facies, Site 915, with results of grain-size and mineralogic analysis. Roman numerals in Lithology column refer to lithologic units. The conglomerate is part of lithologic Unit III. Abundances of minerals are semiquantitative. For clay minerals, $0 \%=0,1 \%-30 \%=1,31 \%-60 \%=2$, and $>61 \%=3$. For gibbsite, $0=$ absent, $1=$ peak height below median value of peak heights for samples from this hole, and $2=$ peak height above median value. $2.70 / 2.45 \AA$ is the ratio between these two peaks. A value $>0.6$ indicates the presence of hematite in addition to goethite, with increases in values indicating increases in hematite levels. $X=$ a small amount of mineral is present, and tr $=$ trace amount. Smc $=$ smectite, Kao $=$ kaolinite, $\mathrm{Ill}=$ illite, $\mathrm{Gib}=$ gibbsite, $\mathrm{Zeo}=$ clinoptilolite, and $\mathrm{Plg}=$ plagioclase. 


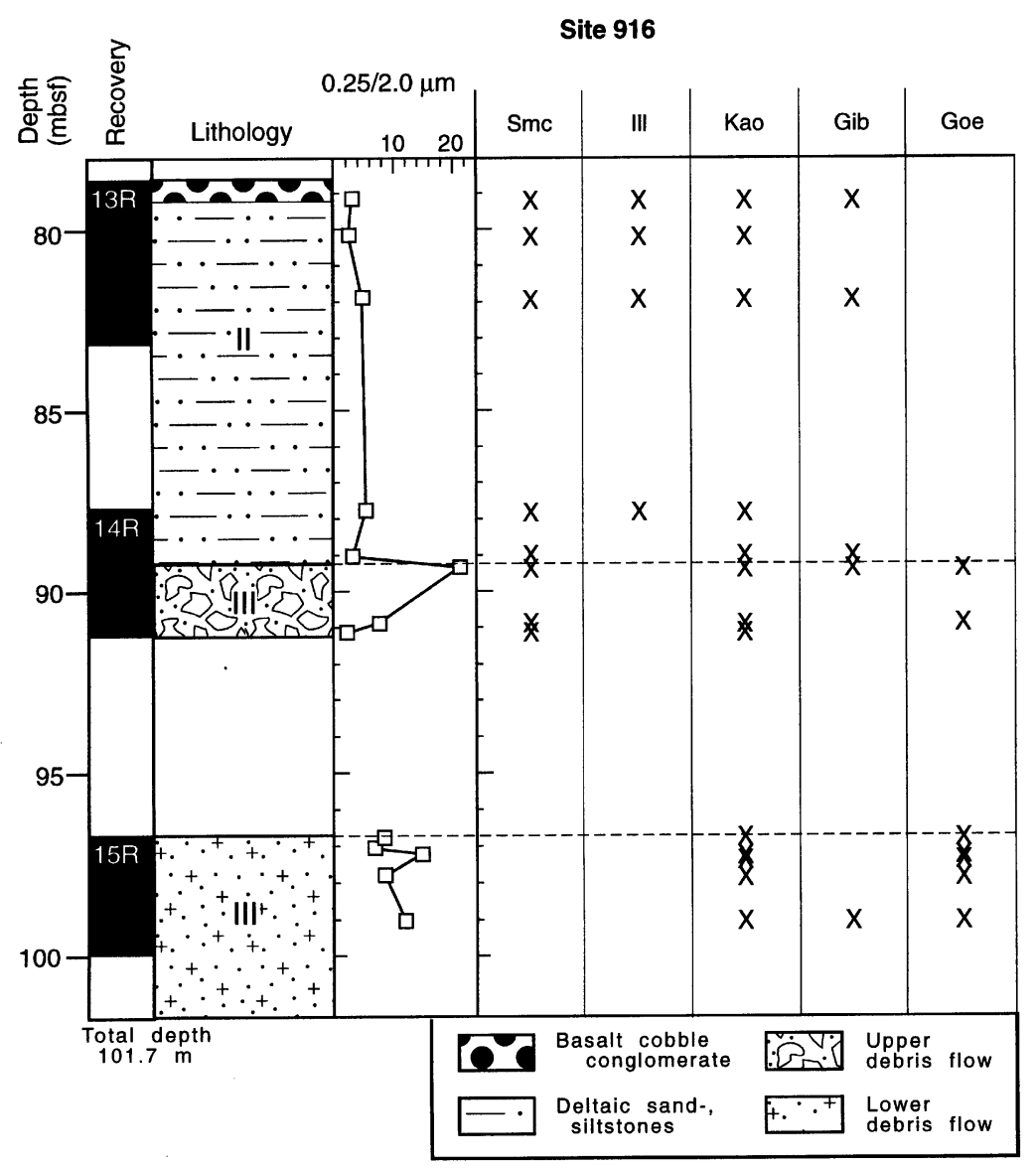

Figure 4. Lithostratigraphy of deltaic and subaerially weathered facies, Site 916 . The ratio of the $0.25-\mu \mathrm{m}$ fraction to the $2-\mu \mathrm{m}$ fraction, as determined by Sedigraph analysis, is given as $0.25 / 2.0 \mu \mathrm{m}$. Abundances of minerals are semiquantitative. $\mathrm{Smc}=$ smectite, $\mathrm{Ill}=$ illite, $\mathrm{Kao}=$ kaolinite, Gib = gibbsite, and Goe = goethite. $\mathrm{mm}$ across (Pl. 2, Fig. 3), to cross-bedded sandstone, to rippled silt and clay (Pl. 2, Fig. 2). This sequence was interpreted as fluvial in origin and coincides with a significant change in the chemical composition of the enveloping lava flows (Larsen, Saunders, Clift, et al., 1994). The mineral composition does not vary within the sequence and comprises dominantly smectite group minerals with a small amount of plagioclase in the clay-size fraction (Fig. 7). Smectite, plagioclase, and quartz comprise the silt fraction. Neither kaolinite nor gibbsite were detected.

Overlying the rift basalt and underlying glaciogenic sediment, 3.7 $\mathrm{m}$ of middle Eocene age sediment (nannofossil Biozone CP14a) were recovered. This sediment is a massive dark green to black volcaniclastic silt, virtually identical in appearance to that recovered as lithologic Unit II at Site 915, and interpreted as sediment deposited on a quiet continental shelf occasionally disturbed by large storms (Larsen, Saunders, Clift, et al., 1994). It overlies a basalt cobble conglomerate similar to that recovered at Sites 915 and 916. The mineral composition of the middle Eocene shelf sediment is similar to that of lithologic Unit II at Site 915, with smectite group minerals illite, kaolinite, and gibbsite present. Quartz, plagioclase, amphibole, and pyroxenes occur in the silt fraction.

\section{Site 918}

A sharp, uneven contact between overlying greensand and underlying reddish brown, highly altered basalt occurs at $1188.52 \mathrm{mbsf}$ in Section 152-918D-96R-3 (Pl. 2, Fig. 4). This weathered basalt persists to $1206.0 \mathrm{mbsf}$. Parent structure of the basalt is visible at the top of this weathered unit and throughout it. The parent structure is so obvious that three igneous units were identified in this interval based on the appearance of lava flow contacts at 1195.77 and 1200.89 mbsf
(Larsen, Saunders, Clift, et al., 1994; Pl. 2, Fig. 5; Fig. 8). Nevertheless, this material is entirely altered to clay and iron sesquioxides. Vesicles and veins are filled with bright red, iron oxides and clay. Interval 152-918D-96R-CC, 23-26 cm, contains drilling biscuits of similar material, with one anomalous biscuit. This biscuit is bright green, similar to the color of malachite. Despite this odd color, no variation in mineral composition was detected between this and the enclosing material. Near the base of the weathered zone, the clay filling the vesicles changes from brown to green. Below the lower contact, vesicles are filled with banded agate. Alteration of the basalts in the form of altered flow tops and bases persists to the base of the hole. These parts of the flows are dull to bright red, with iron oxides, agate, zeolites, and brown or green clay filling vesicles, veins, and fractures.

The ratios of $\mathrm{Si} / \mathrm{Al}, \mathrm{Si} / \mathrm{Fe}$, and mobile bases/Al are the reverse of those of subaerially weathered material. Vertical distribution of $\mathrm{Mg}$ and $\mathrm{Ca}$ is also the opposite of that expected in a subaerial weathering environment (Fig. 9). Iron, Al, and Si levels show little variation with depth within any flow unit or among all flow units. Potassium levels do show a slight decrease from the top of each of the three flow units to their bases, suggesting some downward movement of this ion. However, the K levels are higher than that of the average of the basalt below (Fig. 10; see Fitton, Saunders, et al., this volume). The only mineral containing $\mathrm{K}$ detected in XRD is a small amount of illitic mixed-layering in the smectite group mineral (Fig. 8). Ten percent illite layers in the smectite were determined by comparison of XRD traces to calculated profiles using the NEWMOD program (Reynolds, 1985). This amount of mixed layering is sufficient to account for the $\mathrm{K}$ levels as measured here.

The mineral composition of the weathered zone is dominated by smectite group minerals with varying amounts of kaolinite, goethite, and hematite (Fig. 8). Trace amounts of gibbsite occur in two samples 
Figure 5. Results of XRF analysis, Site $916 . \mathrm{Al}=\%$ aluminum, $\Sigma$ Bases $=\%$ calcium $+\%$ magnesium $+\%$ potassium, $\mathrm{Si}=\%$ silicon, $\mathrm{Fe}=\%$ iron, and $\mathrm{Ti}=\%$ titanium.
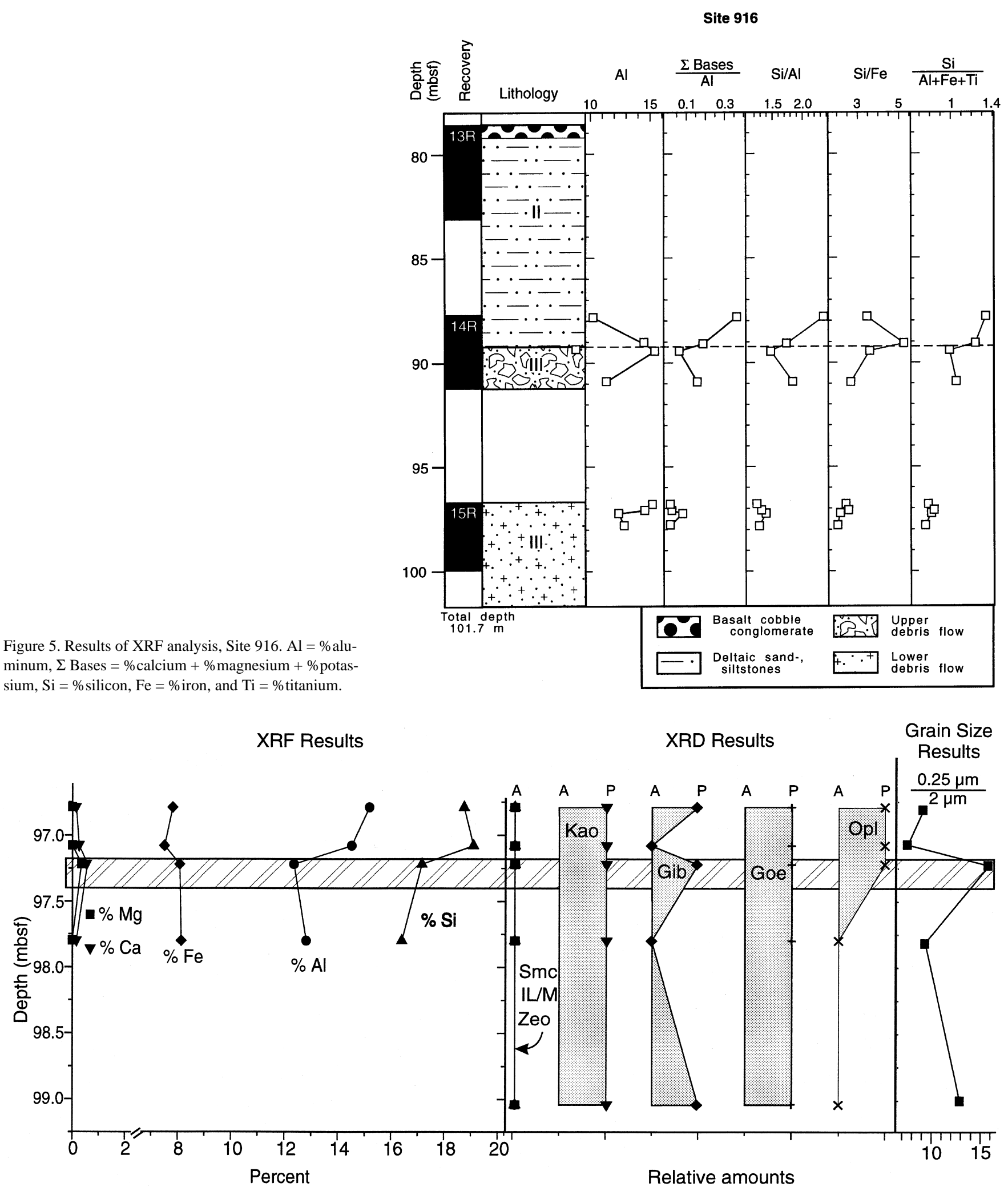

Figure 6. Results of XRF, XRD, and grain-size analyses for Core 152-916A-15R. Almost no Mg or Ca were detected in this material, but a slight elevation occurs in the dendritic calcite vein, indicated by the horizontal shaded box. Al and Si have been concentrated in the upper part of the core by removal of the more mobile bases. No smectite (Smc), illite (Il/M), or zeolite (Zeo) were detected. Kaolinite (Kao) and goethite (Goe) dominate, and there are small amounts of gibbsite (Gib) and opal (Opl). This material is very fine grained, as indicated by the ratio of the $0.25 \mu \mathrm{m}$ to the $2 \mu \mathrm{m}$ size fractions, and it is most fine grained in the hydrothermal vein. $\mathrm{A}=$ mineral is absent, and $\mathrm{P}=$ mineral is present. 


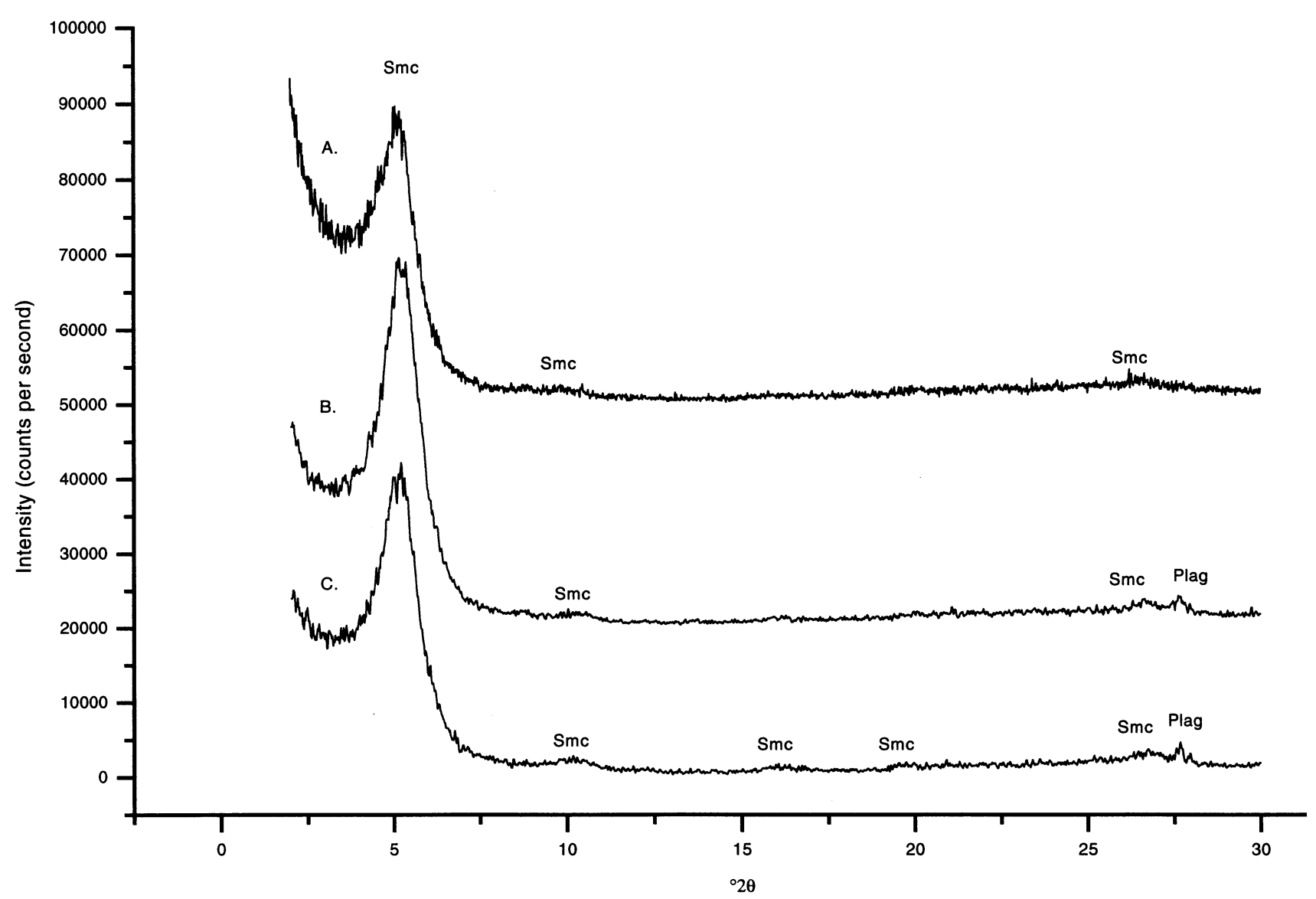

Figure 7. X-ray diffractograms of ethylene glycol-treated, <2- $\mu \mathrm{m}$ fraction, fluvial sediment, Hole 917A. (A) Sample 152-917A-22R-1, 63-67 cm. (B) Sample 152-917A-22R-1, 108-110 cm. (C) Sample 152-917A-22R-1, 141-145 cm. Smc = smectite peaks and Plag = plagioclase feldspar peaks.

and opal is present in the upper two flow units. The mineral composition of the altered tops and bases of underlying lava flows is very pure smectite with varying amounts of hematite, calcite, and opal. Kaolinite occurs only in Sample 152-918D-99R-3, 20-22 cm (1208.62 mbsf).

\section{DISCUSSION \\ Pedogenesis}

Vertical variations in mineral and chemical compositions suggest pedogenesis has affected the volcaniclastic sediment at Site 915, in Core 152-916A-15R, and in the upper three lava flows at Site 918 (Figs. 8, 9). The most clear-cut variations occur at Sites 915 and 916 (Figs. 3, 6). The parent material for the paleosol at Site 915 is the sediment in Cores 152-915A-23R, which is crudely bedded and weakly graded. Debris flows rarely impart such features to a deposit, which suggests this material was deposited from a viscous rather than plastic fluid (Selby, 1994; Enos, 1977; Middleton and Hampton, 1973). Pyroclastic flow deposits may exhibit subtle grading and poor bedding (Fisher and Schmincke, 1994). These may show a lithic concentration zone at the base, a mixed central zone, and a pumice concentration zone at the top. This set of zones appears to be present over interval 152-915A-23R-2, 7-10 cm, with the upper $15-20 \mathrm{~cm}$ of pumice zone subsequently altered by pedogenesis (Pl. 1, Fig. 2). Some of the clasts are rounded and of mixed lithology, suggesting that there was a varied source area that included clasts rounded by subaqueous processes prior to entrainment in either a pyroclastic or viscous permutation of a debris flow.
Features imparted by soil development indicate that the deposit at Site 915 was emplaced on land rather than in a body of water. The red color of the deposit probably developed pedogenically after the material came to rest because the color is best developed along cracks between clasts, and alternates with a yellow brown color (Pl. 1, Fig. 1). This yellow brown color is generally imparted by the presence of goethite or lepidocrocite in excess of hematite (Schwertmann and

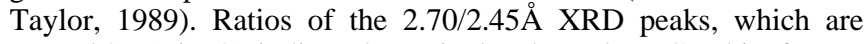
around 0.6 (Fig. 3), indicate hematite levels are low. Goethite formation is favored at lower $\mathrm{pH}$ levels $(\mathrm{pH}$ of about 4$)$ than hematite $(\mathrm{pH}$ of about 6; Schwertmann and Taylor, 1989). Pedogenic processes also caused the formation of kaolinite at the surface and smectite deeper in the profile (Fig. 3). Kaolinite is favored over smectite under acidic, usually subtropical to tropical weathering conditions (Dixon, 1989). Not much information on landscape development can be derived from this paleosol, however. The presence of relict parent structure in all but the uppermost $30 \mathrm{~cm}$ of the profile indicates that either this soil was not deeply weathered or that the upper parts of the soil profile were eroded prior to deposition of the overlying shelf sediment. The indicators that this material was subaerially weathered include the types of minerals (goethite and kaolinite) that are favored by acidic (i.e., nonmarine) conditions, and the variation in the mineral and chemical composition with depth (Figs. 3-6). The latter is imparted by enhanced leaching of the more mobile bases, especially $\mathrm{Mg}, \mathrm{K}, \mathrm{Ca}$, and to a lesser extent, $\mathrm{Si}$, from the upper part of a weathered profile relative to its base (Birkeland, 1984).

At Site 916, the lowermost lithologic unit consists of two separate deposits, as indicated by the presence of smectite and kaolinite in the upper core, but only kaolinite in the underlying core. Kaolinite is the 
Figure 8 . Lithostratigraphy and results of grain-size and mineralogic analyses, Hole 918D. G = glauconite, $\mathrm{Smc}=$ smectite, $\mathrm{Kao}=$ kaolinite, Goe = goethite, $\mathrm{Hem}=$ hematite, and Gib $=$ Gibbsite. The result from the Sedigraph analyses is the $\% 0.25 \mu \mathrm{m} / \% 2 \mu \mathrm{m}$ fraction, showing no zone enriched by clay translocation. The ratio of the $2.70 \AA$ to the $2.45 \AA$ XRD peaks is $2.70 / 2.45$. A ratio of 0.6 indicates the presence of goethite, but no hematite. Numbers to the right of the figure $(2,3$, and $4 \mathrm{~A})$ indicate separate igneous units. Larger ratios indicate increasing levels of hematite.

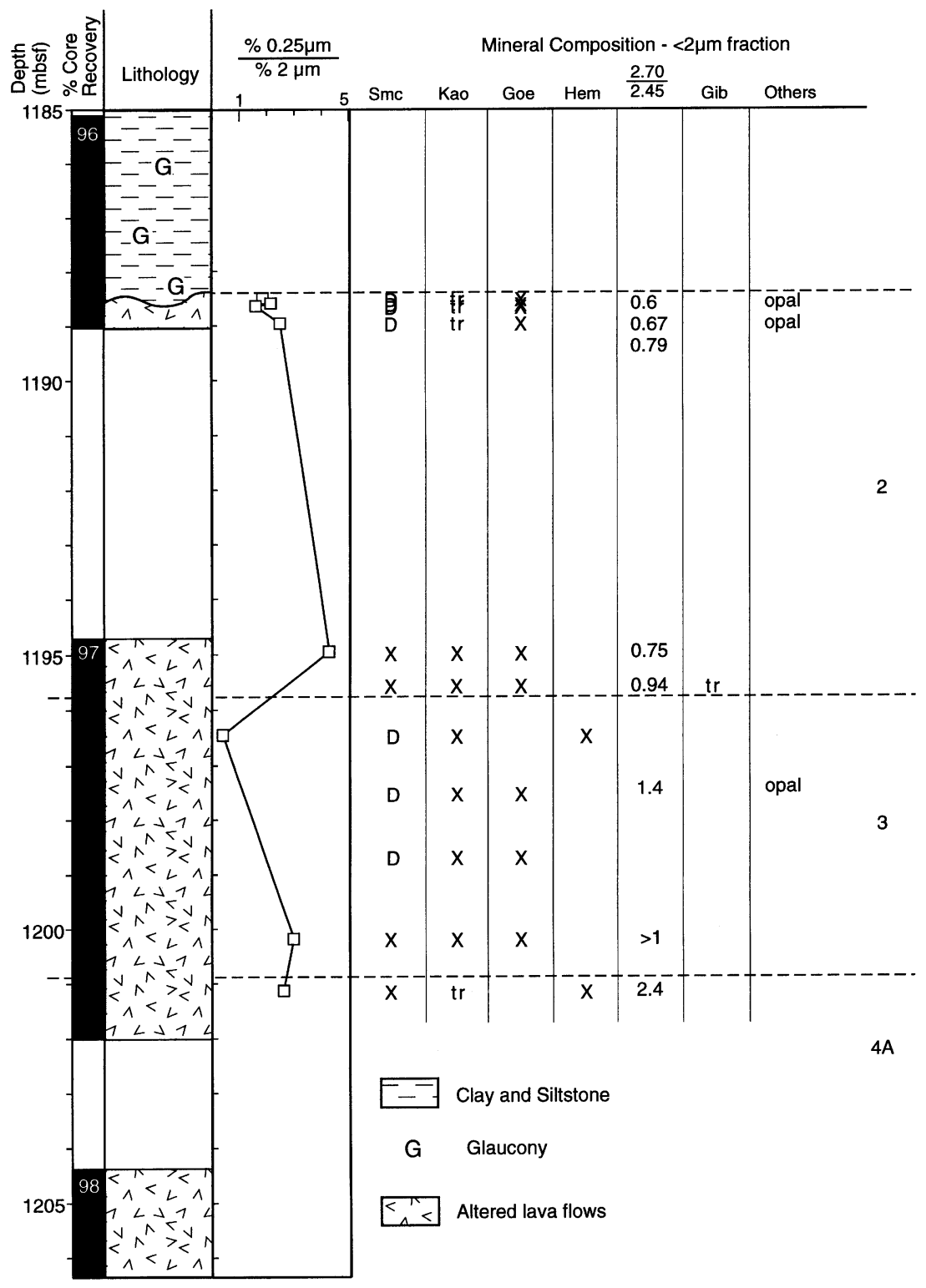

product of more intense weathering of basalt than is smectite (Cawsey and Mellon, 1983). As such, it is more concentrated in the upper parts of a soil profile than the lower. The material in Core 152-916A$15 \mathrm{R}$ has vertical $\mathrm{Al}$ and $\mathrm{Fe}$ distributions that suggest pedogenesis (Fig. 6). Again, the presence of parent sedimentary structure indicates that either this soil was not long in forming or erosion has removed most of it. The calcite vein occurring in this core was probably emplaced after pedogenesis, as it appears to have added a small amount of $\mathrm{Mg}$ and $\mathrm{Ca}$ to the material (Fig. 6). These ions would have been leached during pedogenesis. The vein was probably emplaced at a low temperature, as no high temperature minerals (e.g., chlorite) occur in the vein. Stable $\mathrm{C}$ and $\mathrm{O}$ isotopic data on this calcite are forthcoming. A further indication that the vein emplacement followed pedogenesis is preservation of the delicate dendritic pattern of the calcite (Pl. 2, Fig. 1). This should have given some evidence of dissolution in an environment wet and warm enough to generate kaolinite in the enclosing soil if it had formed while the soil was still exposed to the elements of weathering. Overlying the paleosol is a poorly sorted, matrix-supported conglomerate, with highly variable clasts. Unlike the deposit at Site 915, however, the lack of any bed- ding, grading, or any other indication of deposition from traction load suggests this deposit is the product of a debris flow. This deposit may also have been subject to pedogenesis, as both gibbsite and goethite levels decrease with depth (Fig. 4). Aluminum content, mobile bases/ $\mathrm{Al}$, and $\mathrm{Si} / \mathrm{Al}$ also suggest some pedogenesis has occurred, but more data is needed on this thin unit. The presence of both pyrite and clinoptilolite suggests the influence of either hydrothermal or marine waters as well. Clinoptilolite is a fairly low temperature mineral that may form in marine sediments rich in silica (from volcanic ash or biogenic silica), tuffaceous volcaniclastic deposits, or, more rarely, in basalt at low temperatures $\left(90^{\circ}-150^{\circ} \mathrm{C}\right.$; Gottardi and Galli, 1985).

The material above relatively fresh basalt at Site 918 comprises three flow units, and each of these has been subjected to alteration prior to emplacement of each overlying flow. The presence of kaolinite throughout this lithologic unit indicates that the alteration took place in fresh water, at $\mathrm{pH}$ levels of 6 or lower (e.g., Dixon, 1989). The lack of any vertical variation in either the mineral or chemical composition suggests, again, that either the material was not weathered for very long or that this is the deep part of a soil profile (i.e., a $\mathrm{C}$ horizon). Nahon (1991) estimates that it takes $1000 \mathrm{yr}$ to weather 


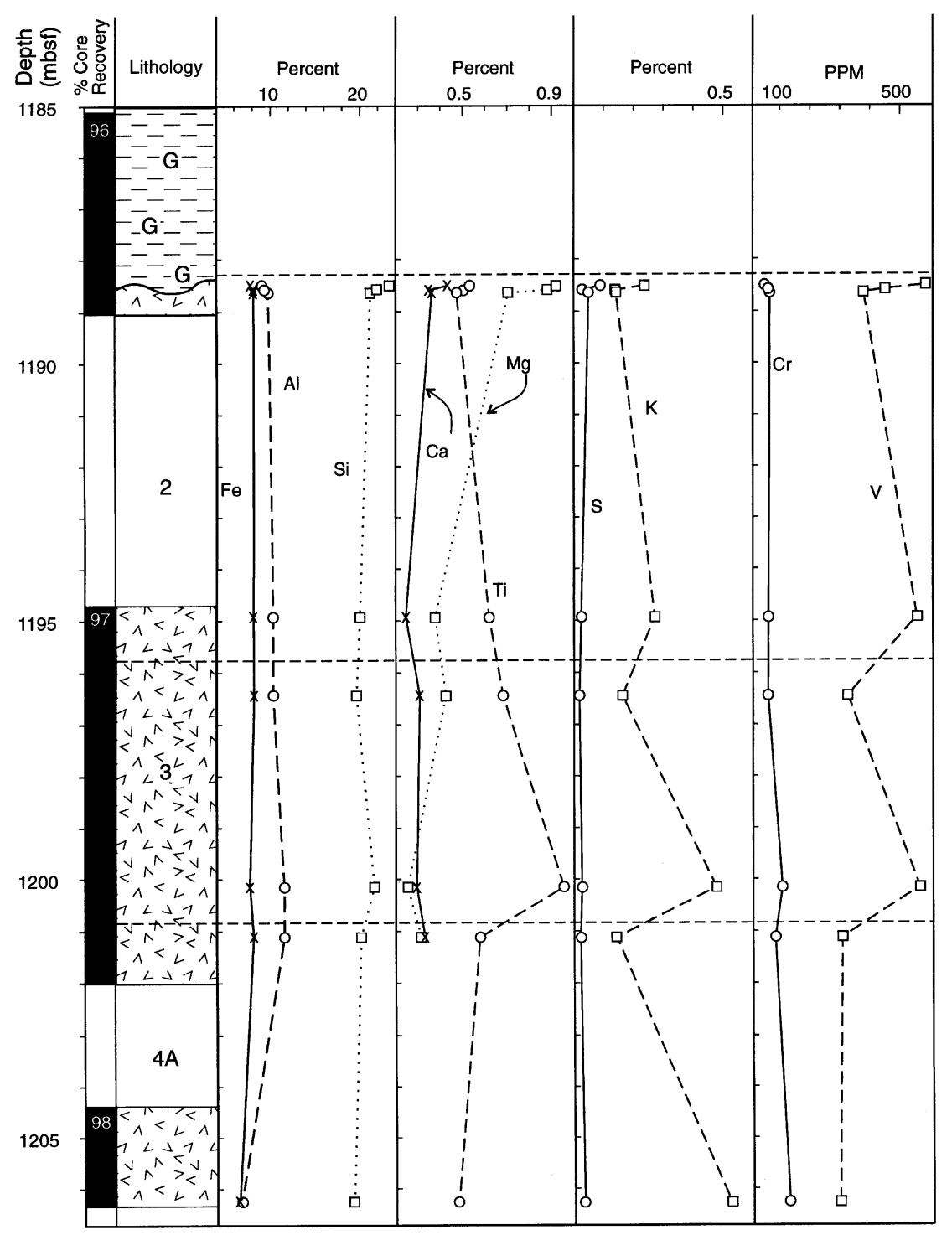

Figure 9. Results of XRF analysis, Site 918. $\mathrm{Fe}=$ \%iron, $\mathrm{Al}=\%$ aluminum, $\mathrm{Si}=\%$ silicon, $\mathrm{Ca}=\%$ calcium, $\mathrm{Mg}=\%$ magnesium, $\mathrm{Ti}=\%$ titanium, $\mathrm{S}=\%$ sulfur, $\mathrm{K}=\%$ potassium, $\mathrm{Cr}=\%$ chromium, and $\mathrm{V}=$ \%vanadium. Numbers in the Lithology column $(2,3$, and $4 \mathrm{~A}$ ) indicate separate igneous units.
4-40 mm of mafic material to a kaolinitic saprolite. Kaolinite occurs throughout the $17.5 \mathrm{~m}$ of weathered basalt, suggesting a weathering duration from 437,500 to $4.4 \mathrm{~m}$.y. In addition to pedogenic alteration, some process has added $\mathrm{K}$ to this material, as the $\mathrm{K}$ levels are higher than in the parent basalt (Fig. 10). Illite formation at depth in sediment requires a $\mathrm{K}$ source, and in marine sediment that source is generally K-feldspar (Hower et al., 1976). However, there is no K-feldspar or other K source in the basalt, indicating the $\mathrm{K}$ must have come from circulating waters. The distribution profile suggests that the $\mathrm{K}$ source is water circulating upward from depth, rather than diffusion downward from seawater in overlying sediment (Fig. 10). In contrast, there is an increase upward in S content, suggesting that the source for $\mathrm{S}$ here is diffusion downward from marine waters after subsidence (Fig. 9).

A small amount of gibbsite, along with abundant kaolinite, suggests a climate that was wet and warm. The basalts are reversely magnetized and are most likely late Paleocene to early Eocene age (Ali and Vandamme, this volume), while the oldest datable sediment at Site 918 above the paleosol is early Eocene age (Wei, this volume). This indicates that subaerial exposure to this warm, wet climate oc- curred in the late Paleocene and/or early Eocene. Goethite/hematite ratios increase with depth in the paleosol (Fig. 8), indicating no hematite at the top of the preserved part of the paleosol and increasing amounts of hematite with depth. Goethite formation is favored over hematite in soils where climates are warm to cool, in low-lying rather than upland areas, and where there are relatively higher levels of organic matter in the soil (Schwertmann and Taylor, 1989). In contrast, an increase in hematite at the expense of goethite occurs in soils with temperature variations ranging from $8^{\circ}$ to $22^{\circ} \mathrm{C}$ (Schwertmann and Taylor, 1989). The lower the temperature, the longer it would take for the other minerals, particularly kaolinite, to form (Dixon, 1989). Therefore, the goethite/hematite ratios indicate that Site 918 probably never stood in an upland area, but rainfall was high enough to generate gibbsite in the soil. It is impossible to know how much gibbsite might have occurred in the upper part of this profile, but in general, high leaching rates favor gibbsite formation over kaolinite (Wollast, 1967), as do moderate $\mathrm{pH}$ levels (6-7) and low concentrations of organic acids (Curtis, 1970; Reynolds, 1971). The presence of goethite, abundant kaolinite, and sparse gibbsite all suggest a warm to temperate, wet climate with low leaching rates, probably due to a high- 


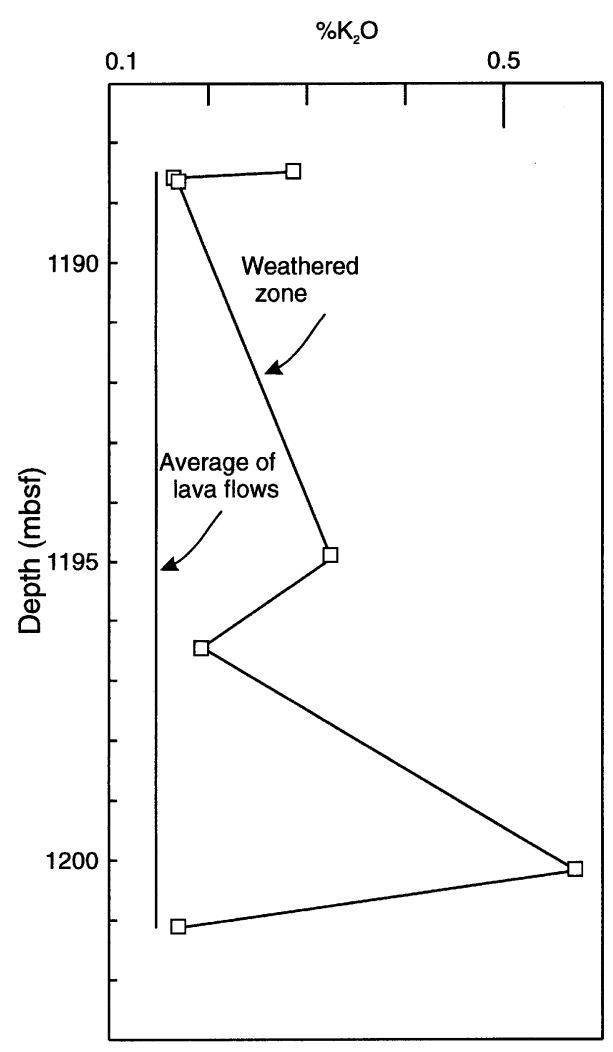

Figure 10. Subaerially weathered zone of Site 918 is enriched in $\% \mathrm{~K}_{2} \mathrm{O}$ relative to the average $\mathrm{K}_{2} \mathrm{O}$ content of 15 lava flows beneath the weathered zone $\left(\% \mathrm{~K}_{2} \mathrm{O}\right.$ in lava flows courtesy of Fitton, Saunders, et al., this volume).

standing water table, as expected in a low-lying area. Organic matter levels were high enough to favor goethite.

The lava flow tops and bases in Cores 152-918D-99R through $113 \mathrm{R}$ are all altered to dominantly smectite and hematite, with less opal (as chalcedony) and calcite. None of these minerals uniquely indicates either the freshwater or marine realm. This mineral paragenesis has been reported as the product of low-temperature seawater weathering of mid-ocean ridge basalt on the southern flank of the Bermuda Rise in the North Atlantic (Humphris et al., 1980). The principal constraint on this mineral suite is that the temperature must be relatively low (Velde, 1985). The absence of goethite and kaolinite suggest only mildly acidic to neutral or alkaline conditions. This alteration might have occurred by meteoric groundwater or by cool $\left(<100^{\circ} \mathrm{C}\right)$ seawater.

\section{Younger Laterite-Derivative Facies and Their Paleoclimatic Implications}

Sediment derived from highly weathered basaltic terranes is designated here on the basis of its red color, mineral composition, or both. These facies include, from oldest to youngest in age, the fluvial sediment intercalated within lava flows at Site 917, the deltaic sediment bearing traces of iron oxide and gibbsite at Site 916, gibbsitebearing green to black sandy mud or muddy sand at Sites 917 and 915, red laminated mud at Site 915, and the younger green to black sandy mud or muddy sand at Site 915 (Fig. 11). Samples from similar but still younger sediment at Site 914 are included for this discussion.

The fluvial sediment at Site 917 occurs between lavas of distinct chemical composition in Core 152-917A-23R (Larsen, Saunders, Clift, et al., 1994), and its occurrence indicates a hiatus in the eruption of the syn-rift basalt. The well-preserved sequence, from very coarse- grained at the base, through cross-bedded sands, to fine silt and clay at the top, suggest a well-developed, meandering stream at this site. The stream was as deep or deeper than the size of the bed forms, which are all only a few tens of centimeters thick. The threshold shear velocity for entrainment of the largest clasts, $4 \mathrm{~mm}$ in size, is about $30 \mathrm{~cm} / \mathrm{s}$ (Allen, 1994). The Hjülstrom diagram (Hjülstrom, 1939) indicates velocities of $20-30 \mathrm{~cm} / \mathrm{s}$ to keep a 4-mm-size particle in motion. Thus a shallow, moderately paced, meandering stream in the lower flow regime would account for the sequence of bed forms observed here. The larger clasts are all bits of only moderately weathered basalt. Quartz is present in the silt-size fraction. The small grain size, the absence of quartz in the sand fraction, and the absence of any other felsic mineral all suggest an eolian origin for the quartz silt. The silt and clay fractions are composed entirely of smectite, hematite, and the primary minerals, plagioclase and magnetite. Such a mineral composition suggests the stream drained a very mildly weathered basaltic terrane, that is, a poorly developed pedotype (sensu Retallack, 1994) with no contribution from a felsic provenance. The absence of kaolinite suggests a limited amount of time for weathering of the basalt. Based on similarities in kaolinite content (derived from the weathering of K-feldspar) in loess deposits from subtropical (Louisiana) to cool temperate (Wisconsin) regions in North America, Dixon (1989) estimated that it takes more than 10,000 years to produce a soil containing pedogenic kaolinite as a major constituent. Soils formed on the island of Hawaii, where surface basalts range in age from 0 to 500,000 yr (Clague and Dalrymple, 1987), are dominated by smectite or semi-amorphous materials such as imogolite or allophane (Foote et al., 1972). They may contain significant amounts of halloysite (Sato et al., 1973; Bates, 1962; Parfitt et al., 1988; Wada and Wada, 1976). Even where rainfall is greater than $1000 \mathrm{~mm} / \mathrm{yr}$ (on the windward side of the island) and the soil has formed from ash, there are no soils on Hawaii Island that are classified in the kaolinitic mineral family (Foote et al., 1972). In contrast, some soils on the older island of Maui are classified in the kaolinitic mineral family (i.e., are dominantly kaolinitic; Foote et al., 1972). The youngest lavas on Maui Island are 800,000 yr. Thus the hiatus between the middle and upper series of lavas at Site 917 lasted no more than 800,000 yr. Any longer hiatus would have allowed kaolinite-rich soils to develop, leaving at least some kaolinite detectable in the fluvial deposits. Kaolinite was not detected in any of the altered lavas from Site 917 (see Demant, this volume).

The deltaic sediment at Site 916 must have been deposited in a marginal marine setting, as a lacustrine setting would not have sufficient sulfate to generate the abundant pyrite-lined and replaced burrows in this sequence. The sediment filled a half-graben (Fig. 2). All of the sand-size sediment is siderite and only a few bright red, hematitic grains remain in this sediment, all suggesting that the original sand-size material was oxidic, ferruginous sediment derived from a highly weathered basaltic terrane that was subsequently reduced and altered to siderite in an organic-rich environment. The mineral paragenesis comprises dominant smectite with some kaolinite and traces of illite and gibbsite in the clay fraction, along with quartz and feldspar in the silt fraction (Fig. 4), all suggesting a mixed provenance. Plagioclase in the silt fraction indicates a source from fresh rather than weathered basalt. Kaolinite, the ferric sand particles (now altered to siderite), and gibbsite indicate a highly weathered source terrane, either mafic or felsic. The abundant iron suggests a source area rich in iron. There may be a third terrane, less weathered than the kaolinite/gibbsitic area, as indicated by the presence of illite. These areas were contributing sediment during the early to middle Eocene, indicating that by this time rivers were tapping quartzose terranes beneath and/or interior to the rift basalt.

Sediment dated as middle Eocene (nannofossil Biozone CP14a) at Sites 917 and 915 indicates subsidence of the central shelf below wave base by this time (Fig. 11). Illite and quartz occur in this sediment, indicating the continued contribution of a felsic source area. 


\begin{tabular}{|c|c|c|c|c|c|c|c|}
\hline & & $\begin{array}{c}\text { Nannofossil } \\
\text { Biozone }\end{array}$ & Hole $917 \mathrm{~A}$ & Hole 916A & Hole $915 \mathrm{~A}$ & Hole $914 \mathrm{~A}$ & Hole $918 \mathrm{D}$ \\
\hline 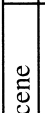 & $\begin{array}{l}\frac{\tilde{\sigma}}{\sigma} \\
\ddot{a}\end{array}$ & CP 18 & & & & $\begin{array}{l}\text { Cores 15-16: } \\
\text { green silt } \\
\text { w/sand beds; } \\
\text { Core 15: 100-250 m }\end{array}$ & $\begin{array}{l}\text { CP 18-19a: } \\
\text { Cores 86-75: } \\
\text { coarse turbidites }\end{array}$ \\
\hline (2) & $\overrightarrow{\bar{z}}$ & CP 16/17 & & & & $\begin{array}{l}\text { Cores 16,17: } \\
\text { green silt } \\
\text { w/sand beds } \\
\text { Core 16: 75-200 m } \\
\end{array}$ & \\
\hline \multirow{5}{*}{ 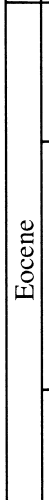 } & 总 & CP 15 & & & $\begin{array}{l}\text { Cores } 14-17: \\
\text { green silt } \\
\text { w/sand beds; } \\
15:<600 \mathrm{~m} \\
17.75-200 \mathrm{~m}\end{array}$ & & \\
\hline & & CP 14b & & & & & \\
\hline & & $?$ & & & $\begin{array}{l}\text { Cores } 18-20: \\
\text { red larninated silt: } \\
\text { no age }\end{array}$ & & \\
\hline & & CP 14a & $\begin{array}{l}\text { Core } 4: \\
\text { green sitt } \\
\text { w/sand beds: }\end{array}$ & & \begin{tabular}{l|} 
Cores $21-22:$ \\
green siti \\
w/sand beds
\end{tabular} & & $\begin{array}{l}\text { Core 88: } \\
\text { Mn crust } \\
\text { 100s-4,000 m }\end{array}$ \\
\hline & 깋 & CP 10 & & $\begin{array}{l}\text { Cores } 13-14: \\
\text { blackhrown silt w/ } \\
\text { wood \& leaf fossils: } \\
\text { no age }\end{array}$ & & & \\
\hline
\end{tabular}

Figure 11. Summary of gibbsite occurrences in Eocene-Oligocene sediment from the East Greenland Shelf (Sites 917-914), and from the Irminger Basin (Site 918). Shaded boxes indicate presence of gibbsite. Type of sediment is given in each box. Paleo-water depths $(\mathrm{m})$ are indicated by benthic foraminifers (Larsen, Saunders, Clift, et al., 1994). Box with solid circles indicates the location of meterthick, calcite-cemented, basalt-cobble conglomerate recovered at Sites 915-917.
The abundance of gibbsite on the East Greenland Shelf indicates a source area with abundant gibbsite generated by subtropical to tropical weathering conditions.

Gibbsite is also present in the overlying laminated red silt at Site 915, with higher levels of goethite, kaolinite, and illite (Figs. 3, 11). The paucity of sand in this unit, its lamination (Pl. 1, Fig. 4), and its complete lack of marine macrofossils or bioturbation suggest more rapid rates of deposition. The mineral composition, which is richer in illite, gibbsite, and kaolinite than the enclosing sediment, suggests a stronger terrestrial influence (Chamley, 1989) than the enclosing (and hence, probably lateral) green-black shelf facies. These features all suggest that this sediment is prodelta mud (Galloway and Hobday, 1983), and a more distal, albeit younger, facies of the interdistributary bay sediment from Site 916 . Both contain abundant iron as sand and silt-size iron sesquioxides. These have been altered to siderite in the organic-rich facies at Site 916, but are preserved in the more organic-poor facies at Site 915. Following this terrestrial interruption, glauconitic green-black muds were again deposited in this area in the late Eocene (nannofossil Zone CP15), which also bear gibbsite, kaolinite, goethite, and illite.

While deltas were feeding terrestrial sediment rich in iron sesquioxides, gibbsite, kaolinite and illite to the East Greenland Shelf, sedimentation in the adjacent Irminger Basin was very slow to nonexistent. A Mn oxide crust indicative of nondeposition occurs in thin volcaniclastic silts of middle Eocene age at Site 918 (Pl. 2, Fig. 6; Larsen, Saunders, Clift, et al., 1994). A sediment dam, possibly a half-horst, must have existed between the shelf area where Sites 914917 were drilled and the Irminger Basin (Fig. 11). The dam was overstepped in the late Oligocene (nannofossil Zones CP18-19a) when quartzose, gravelly to sandy turbidites were deposited at Site 918 (Larsen, Saunders, Clift, et al., 1994).

Gibbsite is not detected in sediment from Site 914 on the East Greenland Shelf that is early Oligocene age and younger (Fig. 11; nannofossil Biozones CP16, 17, and 18). Thus the conditions that generated and/or supplied gibbsite to the shelf disappeared at the end of the Eocene.

\section{SUMMARY AND CONCLUSIONS}

Paleosols formed by the subaerial weathering of basalt and volcaniclastic sediment were identified at Sites 915, 916, and 918. The pa- leosols are either poorly developed or deeply eroded, with only the $\mathrm{C}$ horizons preserved, as indicated by good preservation of primary sedimentary or igneous structures. Two debris flow deposits at Site 916 were subjected to separate subaerial weathering events, as were the upper three lava flows at Site 918. The presence of gibbsite in the soil profiles at Sites 915 and 916, and the absence of caliche at all three sites, indicates that soil conditions were acidic and rainfall was high, on the order of $1000 \mathrm{~mm} / \mathrm{yr}$, during pedogenesis (Retallack, 1994). A high goethite/hematite ratio in the paleosol of Site 918 indicates this soil formed in a low-lying area. A much less weathered pedotype, bearing no kaolinite or goethite, was eroded by a shallow, meandering stream to form the fluvial sediment recovered between the middle and upper volcanic series at Site 917.

The presence of quartz and illite in the pre- or syn-middle Eocene deltaic sediment at Site 916 indicates that rivers had eroded through the basaltic edifice and were tapping felsic terranes interior to or beneath the rift basalts by this time. The mineral composition of the sediments on the shelf records the warm to temperate, wet climate of the Eocene in the form of abundant gibbsite in marine sediment. Kaolinite and goethite in paleosols indicate acidic, organic-rich conditions in low-lying areas. Kaolinite, gibbsite, and goethite persist in sediment through late Eocene age, but are not present in early Oligocene age sediment and younger, suggesting a cooling or drying of this region as glaciation onset in Antarctica (Breza and Wise, 1992).

\section{ACKNOWLEDGMENTS}

I would like to thank the reviewers, Warren Huff and Hervé Chamley, for their helpful comments and suggestions. I would also like to thank the people who helped bring this paper together, including my lab assistants who prepared samples for and ran the Sedigraph and XRD: Kraig Heiden, Justin Spence, Connie Kaplan, Holly Wissenk, and Brandon Wilken. Mr. Joe Denning and the staff of the UNL Soils Testing Lab provided the XRF results. Thanks to Ron Grout and the crew of the JOIDES Resolution for providing us with great core during some pretty harrowing North Atlantic weather, to the really excellent ODP marine techs, and to the scientists, hardy and otherwise, who provided a stimulating mental atmosphere to match the high latitude one.

The U.S. Science Advisory Committee (USSAC) provided funding for this study. 


\section{REFERENCES}

Allen, J.R.L., 1994. Fundamental properties of fluids and their relation to sediment transport processes. In Pye, K. (Ed.), Sediment Transport and Depositional Processes: Oxford (Blackwell Sci. Publ.), 25-60.

Bates, T.F., 1962. Halloysite and gibbsite formation in Hawaii. 9th Inter. Conf., Clays Clay Minerals, 9:315-328.

Birkeland, P.W., 1984. Soils and Geomorphology: New York: (Oxford Univ. Press), 60-94.

Biscaye, P.E., 1965. Mineralogy and sedimentation of Recent deep-sea clays in the Atlantic Ocean and adjacent seas and oceans. Geol. Soc. Am. Bull., 76:803-832.

Breza, J.R., and Wise, S.W., Jr., 1992. Lower Oligocene ice-rafted debris on the Kerguelen Plateau: evidence for East Antarctic continental glaciation. In Wise, S.W., Jr., Schlich, R., et al., Proc. ODP, Sci. Results, 120: College Station, TX (Ocean Drilling Program), 161-178.

Brown, G., 1980. Associated minerals. In Brindley, G.W., and Brown, G. (Eds.), Crystal Structures of Clay Minerals and Their X-ray Identification. Mineral. Soc. Monogr. London, 5:361-410.

Brown, G., and Brindley, G.W., 1980. X-ray diffraction procedures for clay mineral identification. In Brindley, G.W., and Brown, G. (Eds.), Crystal Structures of Clay Minerals and Their X-ray Identification. Mineral. Soc. Monogr. London, 5:305-359.

Cawsey, D.C., and Mellon, P., 1983. A review of experimental weathering of basic igneous rocks. In Wilson, R.C.L. (Ed.), Residual Deposits: Surface Related Weathering Processes and Materials: Oxford (Blackwell Sci. Publ.), 19-24.

Chamley, H., 1989. Clay Sedimentology: Berlin (Springer-Verlag).

Clague, D.A., and Dalrymple, G.B., 1987. The Hawaiian-Emperor volcanic chain, Part I. Geologic evolution. In Decker, R.W., Wright, T.L., and Stauffer, P.H. (Eds.), Volcanism in Hawaii (Vol. 1). Geol. Surv. Prof. Pap. U.S., 1350:5-54.

Curtis, C.D., 1970. Differences between lateritic and podzolic weathering. Geochim. Cosmochim. Acta, 34:1351.

Dixon, J.B., 1989. Kaolin and serpentine group minerals. In Dixon, J.B., and Weed, S.B. (Eds.), Minerals in Soil Environments (2nd ed.). Soil Sci. Soc. Am., 467-525.

Drever, J.I., 1973. The preparation of oriented clay mineral specimens for Xray diffraction analysis by a filter-membrane peel technique. Am. Mineral., 58:553-554.

, 1982. The Geochemistry of Natural Waters: London (PrenticeHall).

Enos, P., 1977. Flow regimes in debris flow. Sedimentology, 24:133-142.

Fisher, R.V., and Schmincke, H.-U., 1994. Volcaniclastic sediment transport and deposition. In Pye, K. (Ed.), Sediment Transport and Depositional Processes: Oxford (Blackwell Sci. Publ.), 351-388.

Foote, D.E., Hill, E.L., Nakamura, S., and Stephens, F., 1972. Soil Survey of the Islands of Kauai, Oahu, Maui, Molokai, and Lanai, State of Hawaii: Washington (U.S. Govt. Printing Office).

Galloway, W.E., and Hobday, D.K., 1983. Terrigenous Clastic Depositional Systems: New York (Springer-Verlag).

Goldbery, R., 1982. Paleosols of the Lower Jurassic Mishor and Ardon formations ("Laterite Derivative Facies"), Makhtesh Ramon, Israel. Sedimentology, 29:669-690.

Gottardi, G., and Galli, E., 1985. Natural Zeolites: Berlin (Springer-Verlag).

Hower, J., Eslinger, E.V., Hower, M.E., and Perry, E.A., 1976. Mechanism of burial metamorphism of argillaceous sediment. 1. Mineralogical and chemical evidence. Geol. Soc. Am. Bull., 87:725-737.

Hjülstrom, F., 1939. Transportation of detritus by moving water. In Trask, P.D. (Ed.), Recent Marine Sediments-A Symposium. Soc. Econ. Paleontol. Mineral., 5-31.

Humphris, S.E., Thompson, R.N., and Marriner, G.F., 1980. The mineralogy and geochemistry of basalt weathering, Holes 417A and 418A. In Don- nelly, T., Francheteau, J., Bryan, W., Robinson, P., Flower, M., Salisbury, M., et al., Init. Repts. DSDP, 51, 52, 53: Washington (US Govt. Printing Office), 1201-1217.

Jackson, M.L., 1975. Soil Chemical Analysis-Advanced Course (2nd ed.): Madison, WI (Published by the author).

Jones, J.B., and Segnit, E.R., 1971. The nature of opal. I. Nomenclature and constituent phases. J. Geol. Soc. Aust., 18:57-68.

Knudsen, D., Clark, R.B., Denning, J.L., and Pier, P.A., 1981. Plant analysis of trace elements by X-ray. J. Plant Nutri., 3:61-75.

Larsen, H.C., Saunders, A.D., Clift, P.D., et al., 1994. Proc. ODP, Init. Repts., 152: College Station, TX (Ocean Drilling Program).

Middleton, G.V., and Hampton, M.A., 1973. Sediment gravity flows: mechanics of flow and deposition. In Middleton, G.V., and Bouma, A.H. (Eds.), Turbidites and Deep Water Sedimentation. Short Course Notes, Soc. Econ. Paleontol. Mineral., Pacific. Sect., 1-38.

Miller, J., 1988. Microscopical techniques: I. Slices, slides, stains and peels. In Tucker, M. (Ed.), Techniques in Sedimentology: Oxford (Blackwell Sci. Publ.), 90-91.

Moore, D.M., and Reynolds, R.C., Jr., 1989. X-ray Diffraction and the Identification and Analysis of Clay Minerals: Oxford (Oxford Univ. Press).

Nahon, D.B., 1991. Introduction to the Petrology of Soils and Chemical Weathering: New York (Wiley).

Nilsen, T.H., and Kerr, D.R., 1978. Paleoclimatic and paleogeographic implications of a lower Tertiary laterite (latosol) on the Iceland-Faeroe Ridge, North Atlantic region. Geol. Mag., 115:153-236.

Parfitt, R.L., Childs, C.W., and Eden, D.N., 1988. Ferrihydrite and allophane in four andepts from Hawaii and implications for their classification. Geoderma, 41:223-241.

Retallack, G.J., 1994. A pedotype approach to latest Cretaceous and earliest Tertiary paleosols in eastern Montana. Geol. Soc. Am. Bull., 106:13771397.

Reynolds, R.C., Jr., 1971. Clay mineral formation in an alpine environment. Clays Clay Miner., 19:361-374.

1980. Interstratified clay minerals. In Brindley, G.W., and Brown, G. (Eds.), Crystal Structures of Clay Minerals and Their X-ray Identification. Mineral. Soc. Monogr:, 5:249-303.

1985. NEWMOD® a Computer Program for the Calculation of One-Dimensional Diffraction Patterns of Mixed-Layered Clays: Hanover, NH (Published by the author, 8 Brook Rd.).

Sato, H.H., Ikeda, W., Paeth, R., Smythe, R., and Takehiro, M., Jr., 1973. Soil Survey of the Island of Hawaii, State of Hawaii: Washington (U. S. Govt. Printing Office).

Schwertmann, U., and Taylor, R.M., 1989. Iron oxides. In Dixon, J.B., and Weed, S.B. (Eds.), Minerals in Soil Environments (2nd ed.). Soil Sci. Soc. Am., 379-438.

Selby, M.J., 1994. Hillslope sediment transport and deposition. In Pye, K. (Ed.), Sediment Transport and Depositional Processes: Oxford (Blackwell Sci. Publ.), 61-87.

Velde, B., 1985. Clay Minerals: A Physico-Chemical Explanation of Their Occurrence: Amsterdam (Elsevier), Dev. Sedimentol., 40.

Wada, K., and Wada, S.-I., 1976. Clay mineralogy of the B horizons of two hydrandepts, a torrox and a humitropept in Hawaii. Geoderma, 16:139157.

Wollast, R., 1967. Kinetics of the alteration of K-feldspar in buffered solutions at low temperature. Geochim. Cosmochim. Acta, 31:635.

\footnotetext{
Date of initial receipt: 1 November 1995

Date of acceptance: 15 May 1996

Ms 152SR-204
} 

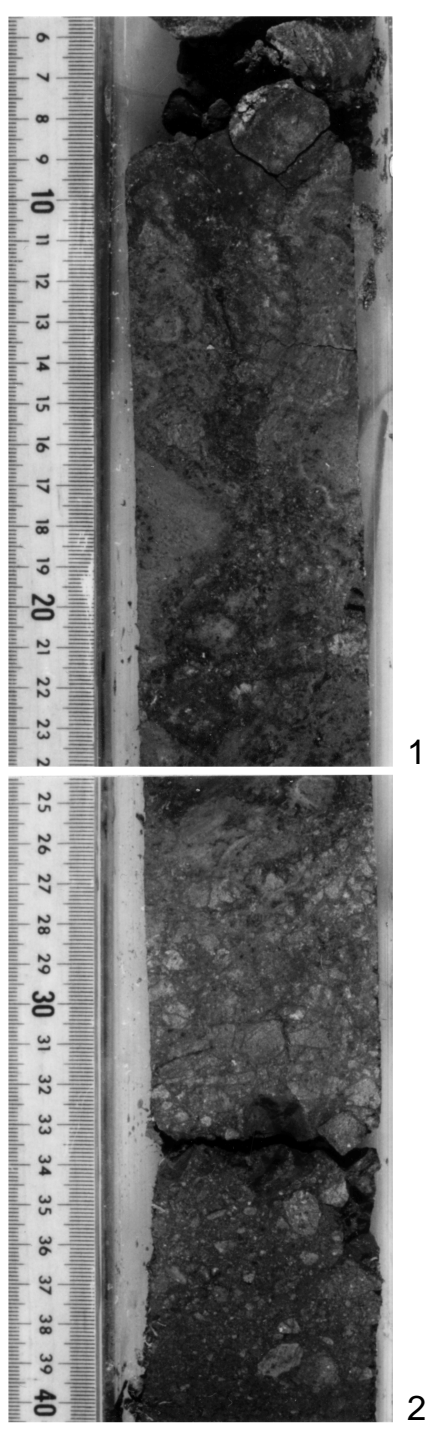

2

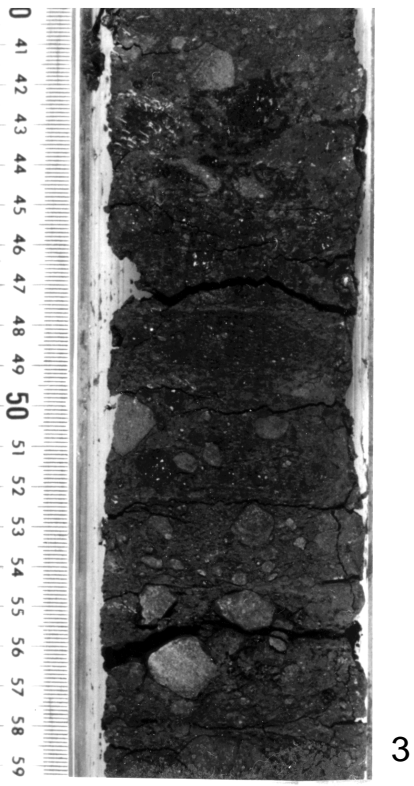

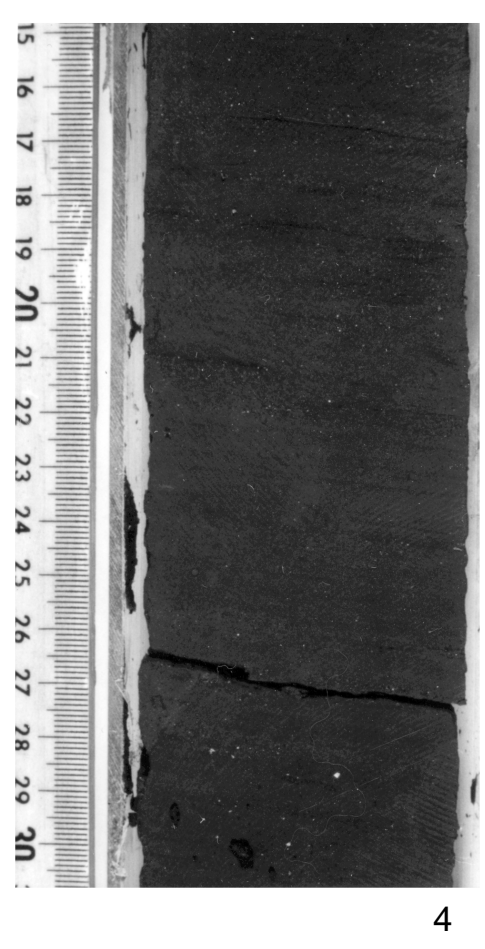

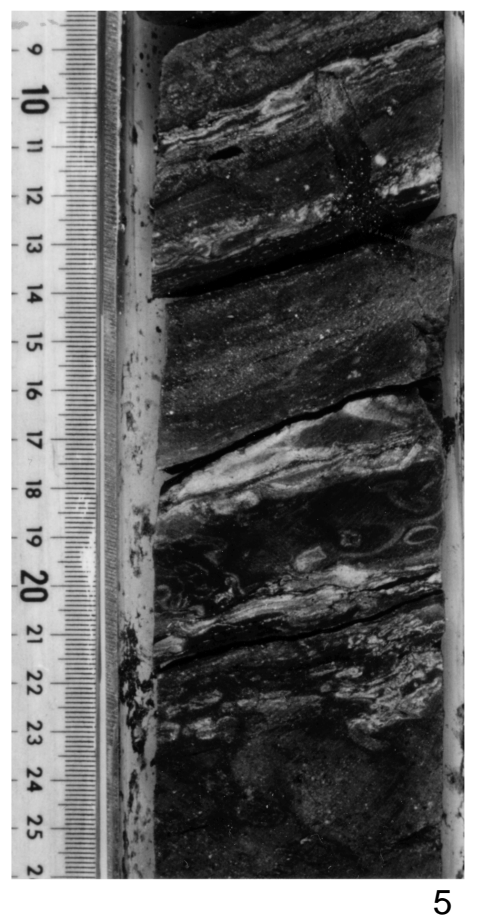

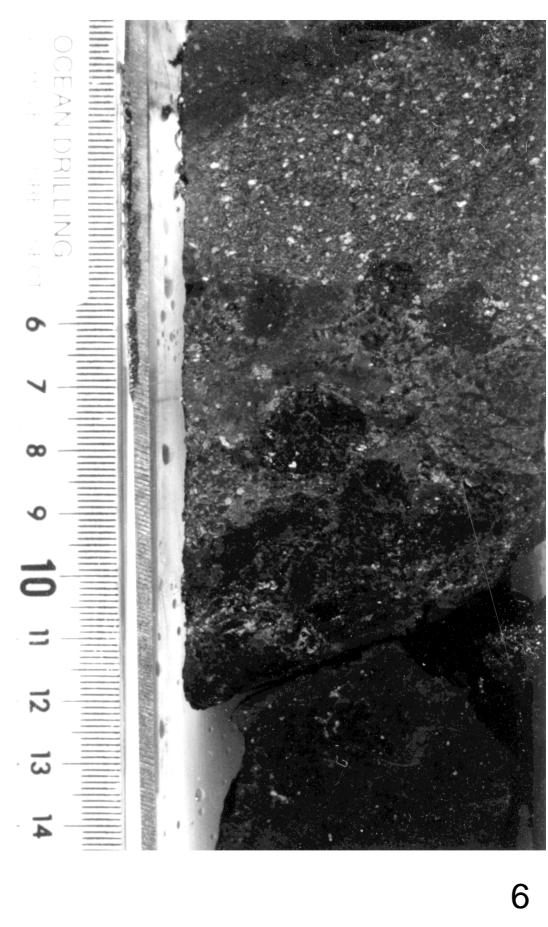

Plate 1. Core photos from shelf sites drilled during Leg 152. 1. Sample 152-915A-23R-1, 7-23 cm. Uppermost part of altered basalt zone, now entirely altered to kaolinite and goethite. Parent structure of pebbles from original volcaniclastic deposit are visible below $20 \mathrm{~cm}$. 2. Sample 152-915A-23R-1, 20-40 cm. Upper part of possible pyroclastic flow, showing concentration of lighter, large clasts. This interval is also entirely altered to kaolinite and goethite. 3. Sample 152-915A-23R-1, $40-60 \mathrm{~cm}$. Crudely bedded and graded sediment, deposited by a dilute debris flow or the base of a pyroclastic flow. 4. Sample 152-915A-20R-1, 15-31 cm. Laminated clayey silt, dusky red in color, deposited as prodelta mud during the middle or late Eocene. 5. Sample 152-916A-13R-2, 15-23 cm. More proximal deltaic facies filled the half-graben at Site 916. Convolute laminae in this photo and all light material are composed of siderite, an alteration product from the original sandy material, which was probably some type of iron sesquioxide. Wood, pyrite, and entire leaves are also present in this sediment. 6. Sample 152-916A-14R-2, 0-13 cm. Soft, clayey clasts were deposited from a debris flow and were later compacted, causing the clasts to flow into one another. This deposit was emplaced atop a subaerially weathered soil (see Pl. 2, Fig. 1). 

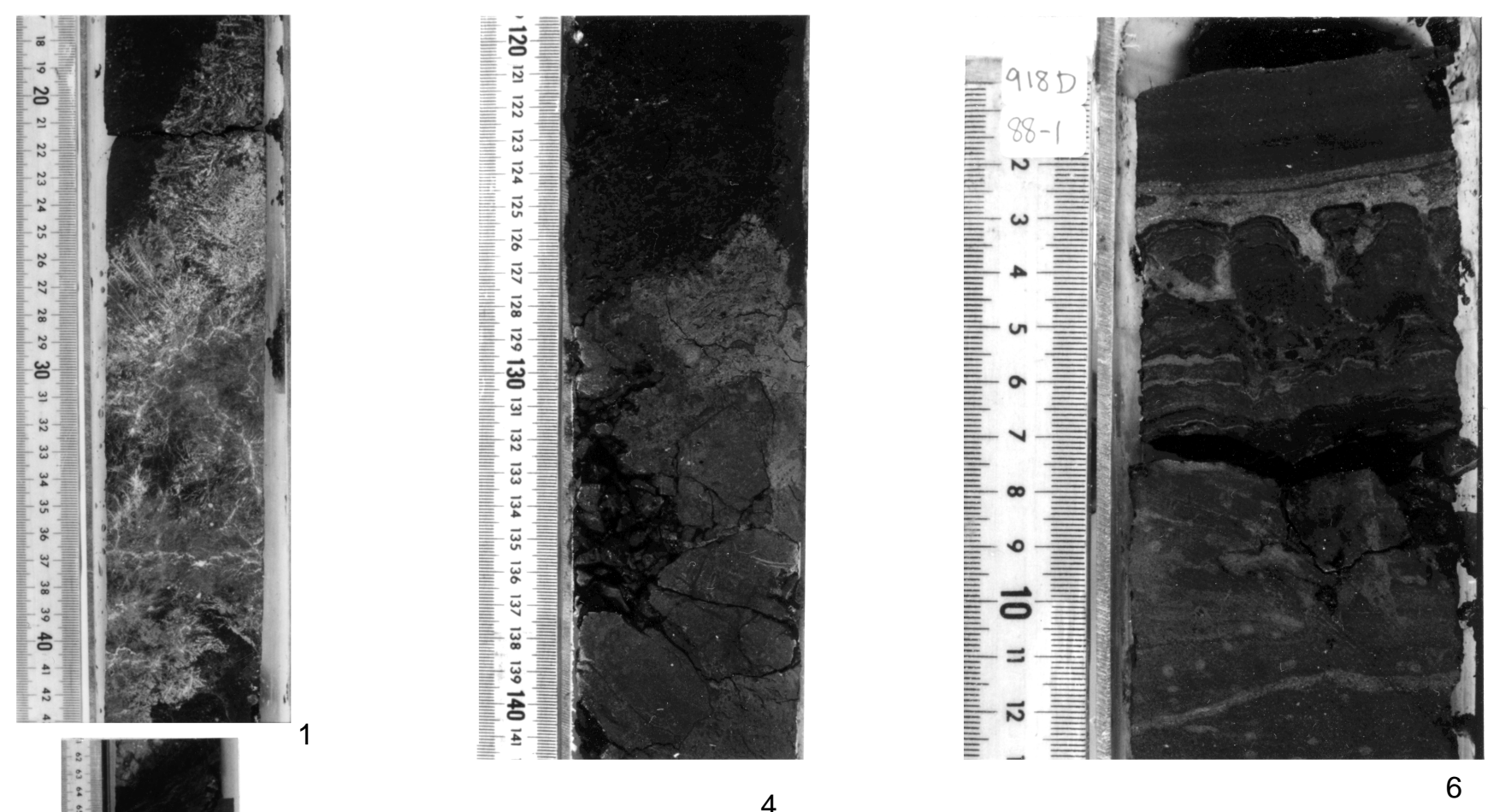

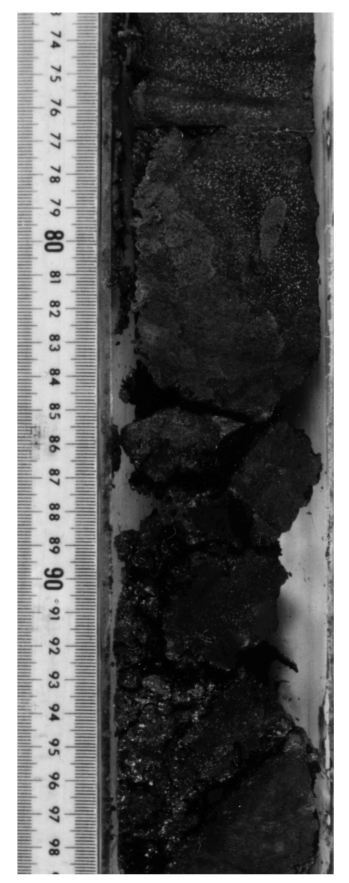

5
Plate 2. Core photos from Sites 916, 917, and 918. 1. Sample 152916A-15R-2, 15-40 cm. Dendritic calcite vein emplaced after soil development at Site 916. 2. Sample 152-917A-22R-1, 60-100 cm. Top of fluvial sequence deposited between eruption of middle and upper series of lavas at Site 917. Cross-bedded sand at the base gives way to laminated silt and clay at the top. The mineral composition is immature, comprising smectite, iron sesquioxides, and plagioclase, with quartz in the silt fraction. This paragenesis indicates minimal weathering of the basaltic, East Greenland landscape in the Paleogene. Quartz is probably of eolian origin. 3. Sample 152-917A-22R-1, 80-110 cm. Base of fluvial sediment illustrated in Fig. 2. Gravel is composed of moderately weathered basalt and soft pebbles composed of iron sesquioxide and smectite. The latter are rip-up clasts from immature soils. 4. Sample 152-918D-96R-3, 120-140 cm. The contact between greensand and subaerially weathered basalt at Site 918 in the Irminger Basin. Structure of the parent basalt as vesicles and veins, now filled with clay and iron sesquioxides, indicates that this is from the deep part of a deeply eroded soil profile or an only moderately weathered soil. 5 . Sample 152-918D-97R-2, 73-97 cm. Base of flow from igneous Unit 2 is indicated by abundant vesicles. The contact between flows 2 and 3 occurs at $83 \mathrm{~cm}$. 6. Sample 152-918D-88R-1, 0-12 cm. Manganese oxide crust formed in the Irminger Basin in the middle Eocene while deltas (Pl. 1, Figs. 4, 5) were bringing iron oxide-rich sediment and gibbsite-rich sediment to the adjacent shelf. A sediment dam as an upthrown half-horst (Fig. 11) starved the Irminger Basin until the late Oligocene, when coarse, gravelly, and sandy turbidites spilled over to Site 918. 